\title{
First experiment approved
}

\section{Washington}

AfTER bringing in their colleague Claudio Bordignon from Milan, Italy, to present the results of animal tests, $R$. Michael Blacse and W. French Anderson of the National Institutes of Health (NIH) have succeeded in convincing a subcommittee of the NIH Recombinant DNA Advisory Committee (RAC) that the time is right to go ahead with the first human gene therapy experiment. The researchers hope to treat children with severe combined immunodeficiency caused by ADA (adenosine deaminase) deficiency - a rare inherited immune disorder affecting fewer than 20 people worldwide - and although the experiment must still be approved by the RAC, the director of NIH and the US Food and Drug Administration, Anderson is optimistic that clinical trials in four children could begin as early as mid-autumn.

With increasing numbers of experiments being submitted for approval there are four in the pipeline - there is concern that the review system will not be able to cope. The subcommittee is trying to carry out "a very critical sentence by sentence review", says Anderson, who feels that "this depth of review is not necessary".

All the new proposals awaiting review by the subcommittee are based upon the first gene transfer experiment, approved in January 1989 (see Nature 337, 294; 1989), which was designed to trace the movement of tumour-infiltrating lymphocytes (TIL) in terminally ill cancer patients. The experiment was very controversial when first proposed, but has since formed the cornerstone of all new gene transfer and gene therapy proposals. In what are referred to as the N2-TIL experiments, Steven Rosenberg of the National Cancer Institute (NCI) isolated TIL cells from a patient's tumour, marked them with a gene for neomycin resistance and readministered them to the patient. Although the gene conferred no therapeutic benefit on the patient, it allowed researchers to track the path of TIL cells in the patient's body and determine whether the cells 'homed' to the tumour to fight the cancer.

With the safety of the N2-TIL gene transfer established, Blacse, of the NCI, and Anderson, of the National Heart, Lung and Blood Institute, plan to move on the "gene therapy" by inserting genes of therapeutic value into children who suffer from ADA deficiency. Using the methods of the N2-TIL experiments, but substituting the patient's own T lymphocytes for TIL cells, researchers hope to correct the ADA deficiency by inserting a normal human ADA gene into the T lymphocytes and returning the gene- corrected cells to the patient.

Of the four new experiments in the pipeline, two almost identical gene transfer experiments have been submitted by $\mathbf{K}$. Brenner of St Jude's Children's Research Hospital in Memphis, Tennessee, and K. Cornetta of the University of Wisconsin. Brenner and Cornetta hope to determine the mechanism of bone marrow reconstitution following autologous bone marrow transplantation (ABMT), in which the patient's own bone marrow is used to treat leukaemias and some solid tumours. Marrow cells can be marked using the N2-
TIL gene transfer system, and tracked when returned to the patient.

Building on his earlier N2-TIL experiments, Rosenberg is hoping to improve the anti-cancer properties of TIL cells by inserting a gene coding for tumour necrosis factor (TNF) - an experimental anti-cancer drug - into TIL cells. In a similar vein, M. T. Lotze of the University of Pittsburgh is looking at ways to improve the targeting and efficacy of TIL cells in patients with malignant melanoma. Performing an identical experiment to the N2-TIL gene transfer study, Lotze plans to study the efiects of administering Il-2 and II-4 in conjunction with TILs.

Diane Gershon

\section{Cleverer ways to kill?}

\section{Washington}

ATTEMPTS by Western nations to combat the huge plague of locusts and grasshoppers that struck Africa in the late 1980 s relied far too much on brawn and far too little on brains, according to an unusually critical report* released from the US Congressional Office of Technology Assessment (OTA) earlier this week.

In a massive campaign led by the US Agency for International Development (AID), some 13 million litres of insecticide were sprayed over 100,000 square kilometres of northwest and northern Africa between 1986 and 1989. As a result, experts claimed, a locust plague was for the first time stopped in its tracks by human intervention. But OTA argues that it is not at all clear whether it was the insecticide or just fortuitous changes in the weather that wiped out the insects.

Rather than taking credit for ending the plague, the report says that AID officials should be taking responsibility for "the mostly uncounted health and environmental costs of insecticide-based control programs; redirecting development funds to emergency efforts; and focusing on a few insects that, while highly visible, do not cause crop losses as great as some other agricultural pests". In 1986, OTA contends, donors spent $\$ 40$ million and succeeded in saving only $\$ 46$ million worth of crops.

A better approach, the OTA says, would accept that most locust upsurges do not result in famine. Instead of major assaults on this one enemy, what are needed in Africa are intelligent integrated pest management and monitoring systems for insects, weather and vegetation. Such an approach would deal with different pests according to their economic impact, would stress prevention over crisis management and would look for long-term development of African agriculture over

* A plague of locusts - special report OTA-F-450 (Washington DC: US Government Printing Office, July 1990).

\section{emergency intervention.}

The report has already provoked a strong response. Senator Patrick Leahy, chairman of the foreign operations subcommittee which funds the AID's locust control programme, described the massive use of insecticides as "absolutely unacceptable" when it costs as much to protect the crops as the crops are worth, let alone health and environmental costs.

Locust experts are united in their support for longer-term integrated pest management, but thiir views of the 1980 s campaign make the OTA report seem too combative. Joyce Magor, head of the department of pest ecology at the UK's Natural Resources Institute, points out that a locust plague is usually stopped by a combination of events: "unusual migrations that send a proportion of the insects to a place where they cannot breed successfully, lack of rain in locust breeding areas and the coincidental arrival of locusts in countries where control is effective". In 1988, a fortuitous air current sent huge swarms of locusts on a final voyage out over the Atlantic, while some well-organized campaigns mopped up huge numbers of locusts. Neither weather nor human intervention alone can expect to take the credit for ending the plague.

Measuring the effectiveness of a campaign in terms of how much damage it averted is a "guessing game" says Magor, "because you would have to estimate where you killed them, and where they would have gone if you had not." In the 1980s plague, swarms crisscrossed northern Africa but spent most of their time in subsistence farming areas. They did not enter the regions of Morocco, for example, where crops are grown to supply out-of-season specialities to Europe and large financial losses might have been recorded. Had human intervention prevented crop loss there, OTA's sums might have added to a different conclusion.

Alun Anderson 